Supplement of Geosci. Model Dev., 12, 3609-3639, 2019

https://doi.org/10.5194/gmd-12-3609-2019-supplement

(C) Author(s) 2019. This work is distributed under

the Creative Commons Attribution 4.0 License.

(c) (1)

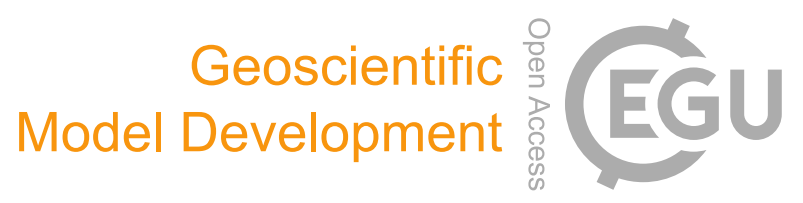

Supplement of

\title{
The global aerosol-climate model ECHAM6.3-HAM2.3 - Part 2: Cloud evaluation, aerosol radiative forcing, and climate sensitivity
}

David Neubauer et al.

Correspondence to: David Neubauer (david.neubauer@env.ethz.ch)

The copyright of individual parts of the supplement might differ from the CC BY 4.0 License. 


\section{L47 vs. L31 and E63H23-GFAS34 and E63H23-10CC}

The simulation of E63H23 with 31 vertical levels (L31) instead of 47 vertical levels (L47) show similar results to L47 (the additional levels are added mostly in the stratosphere; model top increases from $10 \mathrm{hPa}$ to $0.01 \mathrm{hPa}$ ). Table $\mathrm{S} 1$ shows the results of the simulations E63H23-L31, E63H23-GFAS34 and E63H23-10CC which can be compared to the values of

5 E63H23 in Table 2. Also the values for the time period 2000-2009 are shown for E63H23, which are quite similar to those of the time period 2003-2012 in Table 2. Therefore the values of the different model versions in Table 2 can be compared although they cover slightly different time periods. As an example for the similar results for L31 and L47 in E63H23, Figure $\mathrm{S} 1$ shows the global mean IWC as a function of pressure for E63H23 and the two vertical grids, L31 and L47. The IWC lines of both vertical grids lie almost on top of each other.

10 
Table S1. Global mean values of the PD simulations for E63H23 but for the period 2000-2009, E63H23-L31, E63H23GFAS34, E63H23-10CC, E63H23-LL and E63H23-GUELLE. Radiative fluxes are at the top of atmosphere. Values from observations (OBS) and multi-model means (MMM) are shown next to those of the three model versions. $\mathrm{ERF}_{\text {aritaci }}$ and ECS are from the $\mathrm{PD}_{\mathrm{aer}} / \mathrm{PI}_{\mathrm{aer}}$ and $1 \mathrm{xCO} 2 / 2 \mathrm{xCO} 2$ simulations respectively.

\begin{tabular}{|c|c|c|c|c|c|c|c|}
\hline Variable & OBS/MMM & $\begin{array}{c}\text { E63H23 } \\
(2000- \\
2009)\end{array}$ & $\begin{array}{l}\text { E63H23- } \\
\text { L31 } \\
(2003- \\
2012)\end{array}$ & $\begin{array}{c}\text { E63H23- } \\
\text { GFAS34 } \\
(2003- \\
2012)\end{array}$ & $\begin{array}{l}\text { E63H23- } \\
10 \mathrm{CC} \\
(2003- \\
2012)\end{array}$ & $\begin{array}{l}\text { E63H23- } \\
\text { LL } \\
(2003- \\
2012)\end{array}$ & $\begin{array}{c}\text { E63H23- } \\
\text { GUELLE } \\
(2003- \\
2012)\end{array}$ \\
\hline $\mathrm{SW}\left(\mathrm{W} \mathrm{m}^{-2}\right)$ & $240(238$ to 244$)$ & 238 & 238 & 238 & 238 & 240 & 239 \\
\hline $\mathrm{LW}\left(\mathrm{W} \mathrm{m}^{-2}\right)$ & $-239(-237$ to -241$)$ & -238 & -238 & -238 & -238 & -238 & -238 \\
\hline $\operatorname{Net}\left(\mathrm{W} \mathrm{m}^{-2}\right)$ & $0.7 \pm 0.1$ & 0.4 & 0.5 & 0.0 & 0.5 & 1.5 & 1.6 \\
\hline SW CRE $\left(\mathrm{W} \mathrm{m}^{-2}\right)$ & $-47(-46$ to 53.3$)$ & -50 & -50 & -50 & -50 & -49 & -48 \\
\hline LW CRE $\left(\mathrm{W} \mathrm{m}^{-2}\right)$ & $26(22$ to 30.5$)$ & 24 & 24 & 24 & 24 & 24 & 24 \\
\hline Net CRE $\left(\mathrm{W} \mathrm{m}^{-2}\right)$ & $-21(-17.1$ to 22.8$)$ & -26 & -26 & -26 & -25 & -25 & -24 \\
\hline $\mathrm{CC}(\%)$ & $68 \pm 5$ & 69 & 68 & 68 & 69 & 68 & 68 \\
\hline LWP (ocean) $\left(\mathrm{g} \mathrm{m}^{-2}\right)$ & 42.9 to 89.4 & 71 & 71 & 72 & 90 & 65 & 65 \\
\hline $\begin{array}{l}\text { LWP-LP (ocean) }\left(\mathrm{g} \mathrm{m}^{-}\right. \\
\end{array}$ & $73.5 \pm 5.5$ & 77 & 77 & 79 & 101 & 72 & 69 \\
\hline IWP $\left(\mathrm{g} \mathrm{m}^{-2}\right)$ & $25 \pm 7$ & 15 & 15 & 15 & 15 & 15 & 15 \\
\hline $\begin{array}{lr}\text { Cloud-top } & \text { CDNC } \\
\text { (ocean; } & \left.60^{\circ} \mathrm{N}-60^{\circ} \mathrm{S}\right) \\
\left(\mathrm{cm}^{-3}\right) & \end{array}$ & $72 \pm 37$ & 78 & 78 & 84 & 73 & 70 & 67 \\
\hline $\mathrm{CDNC}_{\text {burden }}\left(10^{10} \mathrm{~m}^{-2}\right)$ & - & 3.1 & 3.1 & 3.3 & 2.9 & 2.6 & 2.7 \\
\hline $\operatorname{ICNC}_{\text {burden }}\left(10^{12} \mathrm{~m}^{-2}\right)$ & - & 8.0 & 8.0 & 7.8 & 8.1 & 7.9 & 7.9 \\
\hline $\mathrm{P}\left(\mathrm{mm} \mathrm{d}^{-1}\right)$ & $2.7 \pm 0.2$ & 3.0 & 3.0 & 3.0 & 3.0 & 3.0 & 3.0 \\
\hline Sulfate burden (Tg) & $2.0( \pm 25 \%)$ & 2.2 & 2.3 & 2.4 & 2.4 & 2.2 & 2.2 \\
\hline $\begin{array}{l}\text { Black carbon burden } \\
(\mathrm{Tg})\end{array}$ & $0.2( \pm 42 \%)$ & 0.1 & 0.1 & 0.3 & 0.1 & 0.1 & 0.1 \\
\hline $\begin{array}{l}\text { Particulate organic } \\
\text { matter burden }(\mathrm{Tg})\end{array}$ & $1.7( \pm 27 \%)$ & 1.0 & 1.0 & 2.2 & 1.1 & 1.0 & 1.0 \\
\hline Sea salt burden $(\mathrm{Tg})$ & $7.5( \pm 54 \%)$ & 4.1 & 4.1 & 4.1 & 4.3 & 4.0 & 10.2 \\
\hline $\begin{array}{l}\text { Mineral dust burden } \\
(\mathrm{Tg})\end{array}$ & $19.2( \pm 40 \%)$ & 17.7 & 18.3 & 18.3 & 20.1 & 19.3 & 18.5 \\
\hline $\mathrm{ERF}_{\text {aritaci }}\left(\mathrm{W} \mathrm{m} \mathrm{m}^{-2}\right)$ & $-0.9(-1.9$ to -0.1$)$ & -1.0 & -1.0 & -0.9 & -1.7 & -0.9 & -0.9 \\
\hline $\operatorname{ECS}(\mathrm{K})$ & 1.5 to 4.5 & 2.5 & 2.5 & 2.6 & 2.8 & - & - \\
\hline
\end{tabular}


Cloud ice $\left(\mathrm{mg} \mathrm{kg}^{-1}\right)$

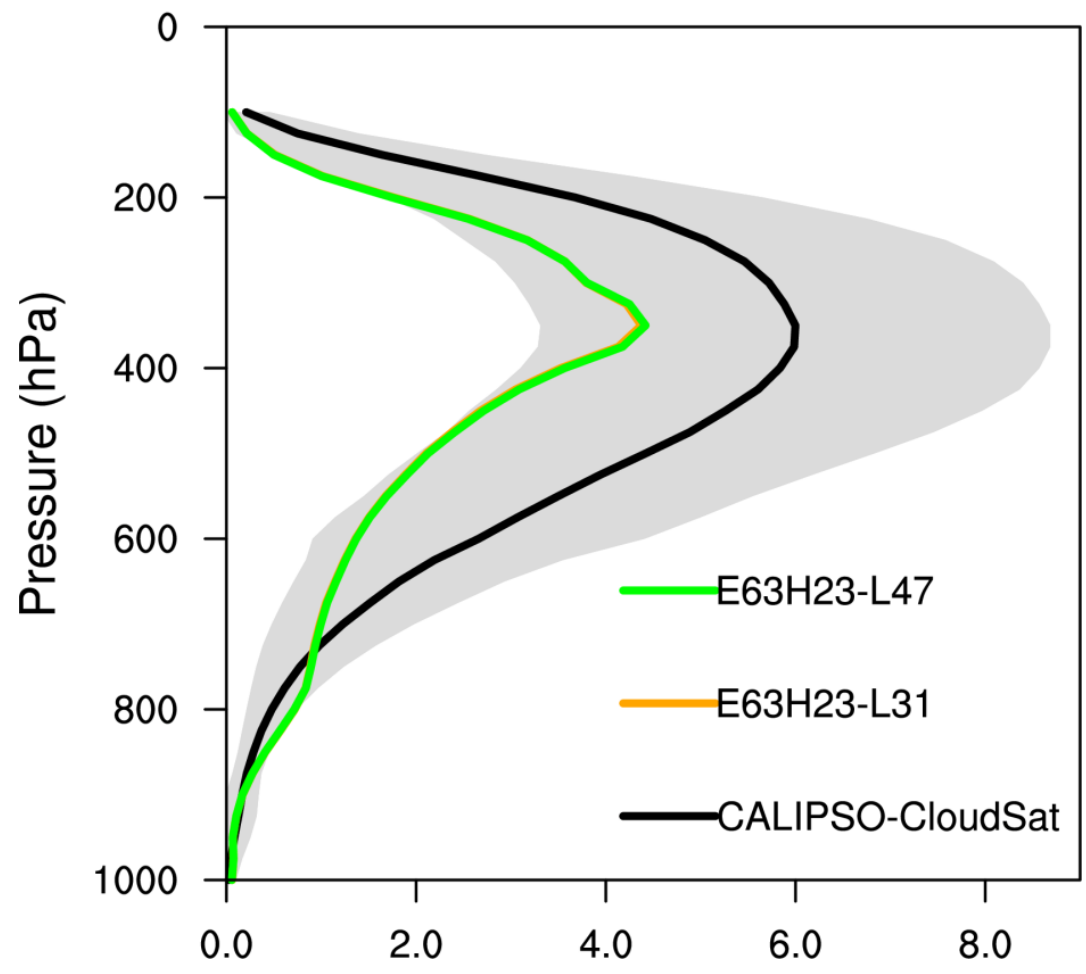

Figure S1: Comparison of global annual mean IWC as a function of pressure of E63H23 for the vertical grids L31 and L47 (default) to CALIPSO/CloudSat observations from $\mathrm{Li}$ et al. (2012). Gray shading indicates the uncertainty in the CALIPSO/CloudSat observations. The CALIPSO/CloudSat data covers the years 2006-2010, model data is from the PD 5 simulations. 


\section{Frequency of convection}
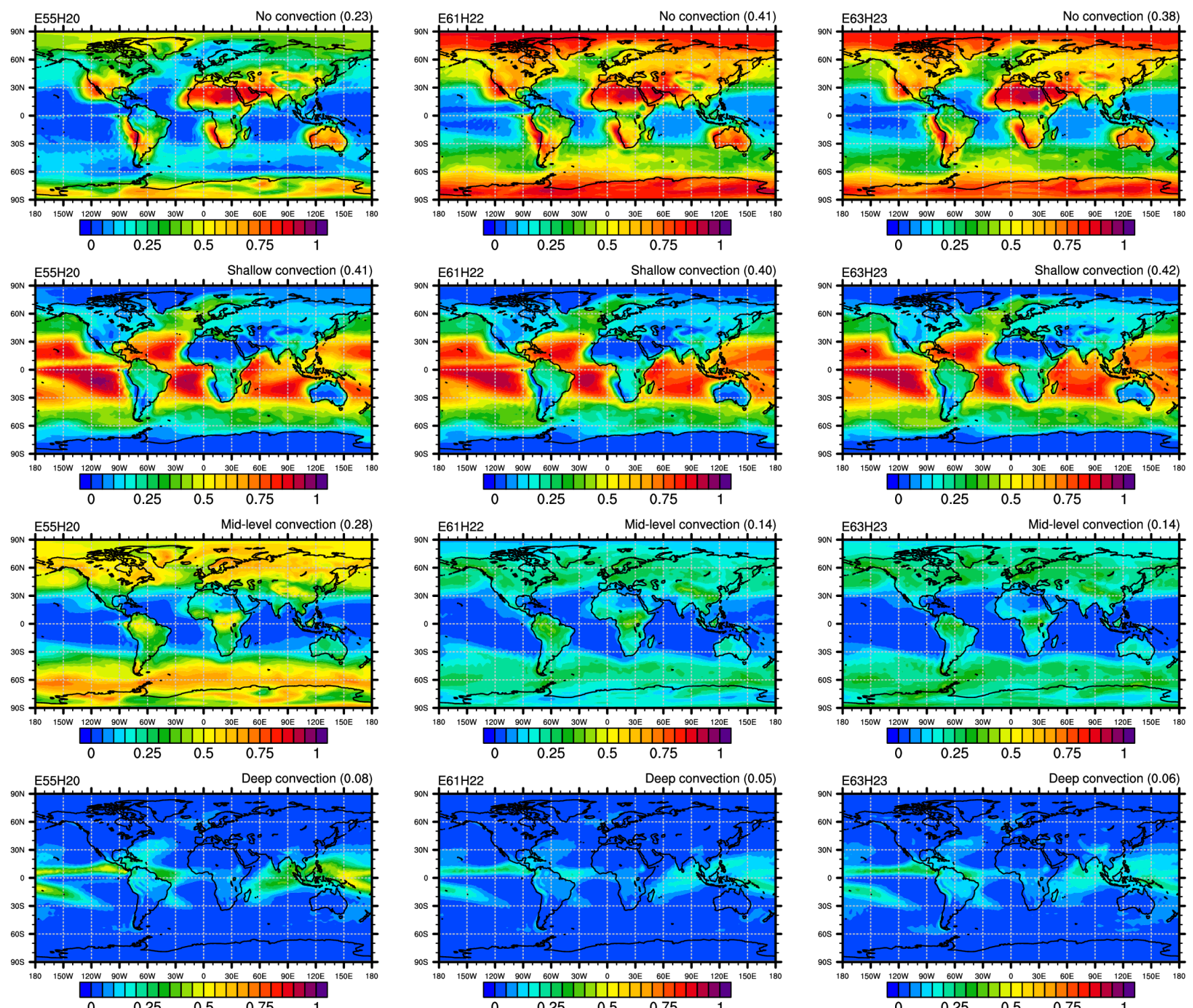

Figure S2: Annual mean frequency of the activation of the convection scheme for the different types of convection in E55H20, E61H22 and E63H23 PD simulations. Global annual mean values are shown in brackets. 

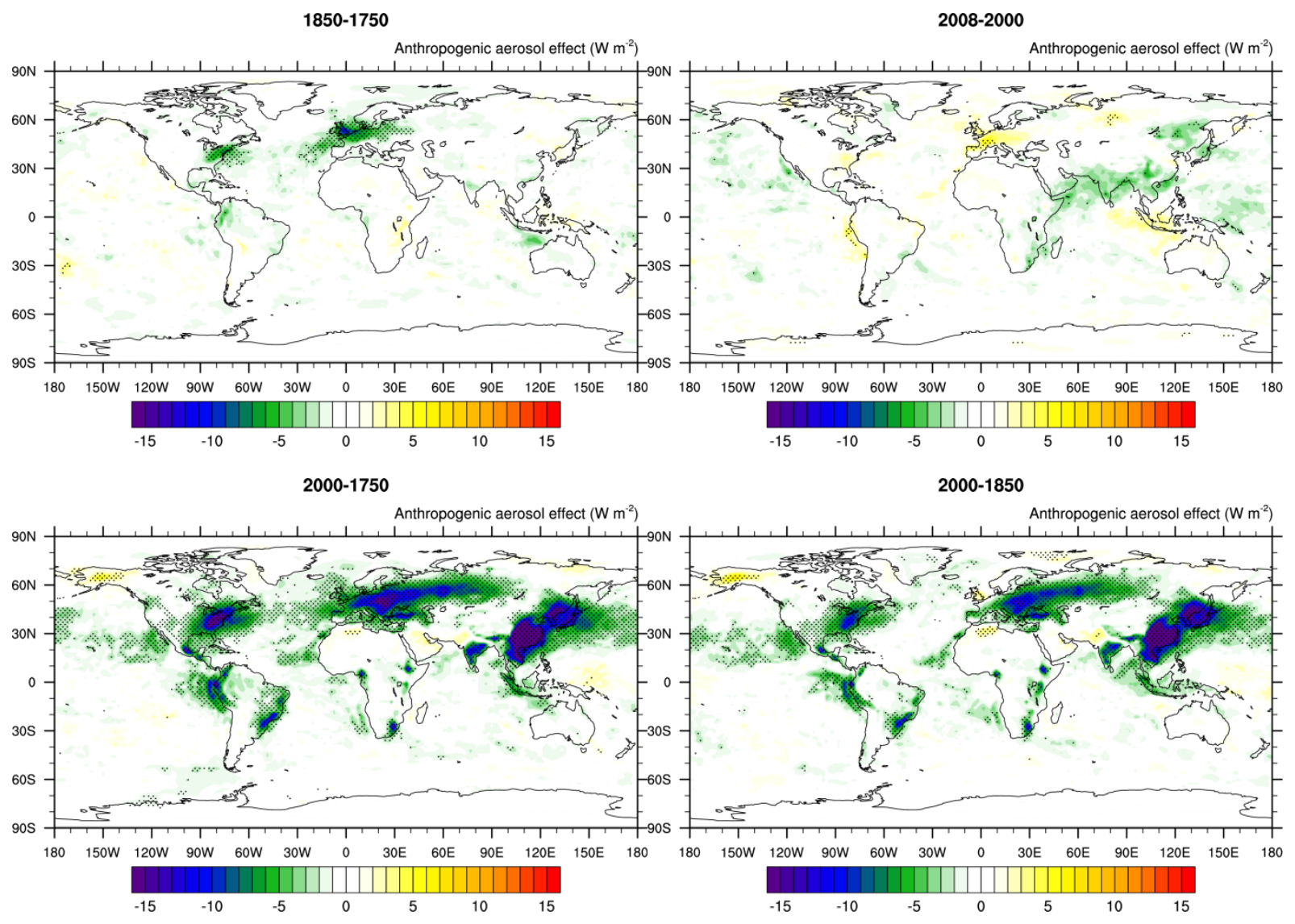

2008-1750 2008-1850

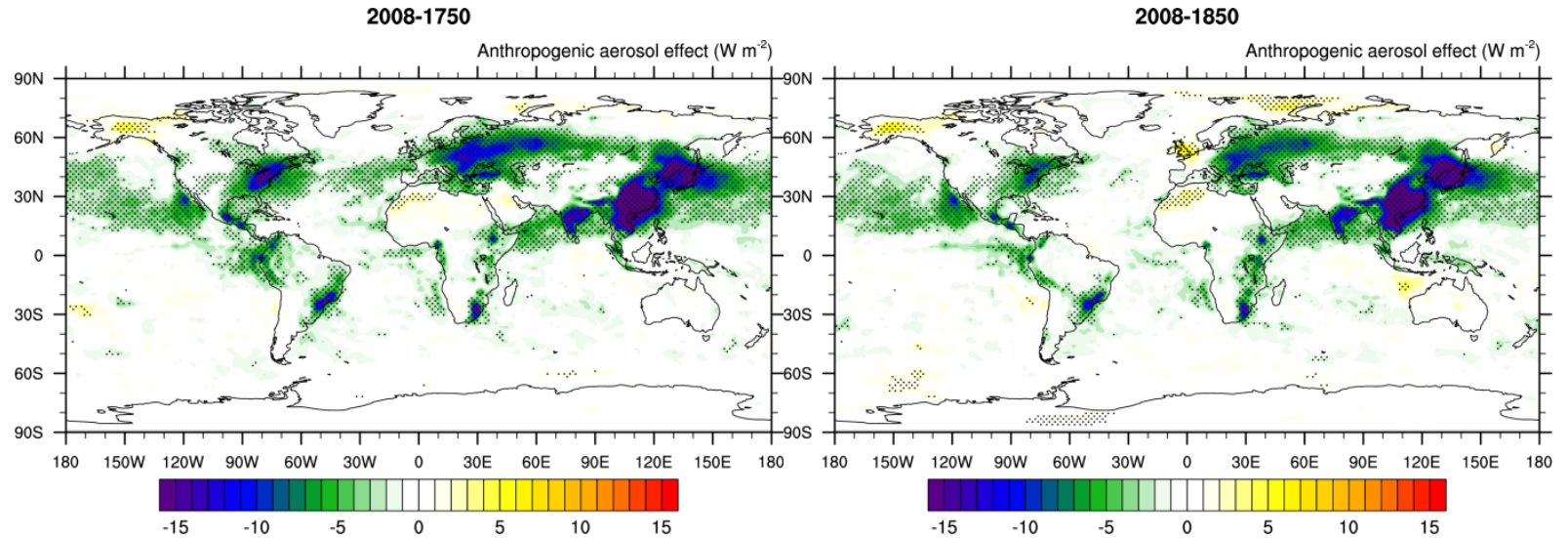

Figure S3: Global maps of Net $\mathrm{ERF}_{\text {ariaci }}$ of $\mathbf{E} 63 \mathrm{H} 23$ from 20 year free simulations with present day minus pre-industrial aerosol 10 emissions $\left(\mathbf{P D}_{\mathrm{aer}}-\mathbf{P I}_{\mathrm{aer}}\right)$. Different years are used to represent present day and pre-industrial aerosol emissions. Hatching indicates statistically significant differences at the $95 \%$ significance level. The false discovery rate is controlled following Wilks (2016). 


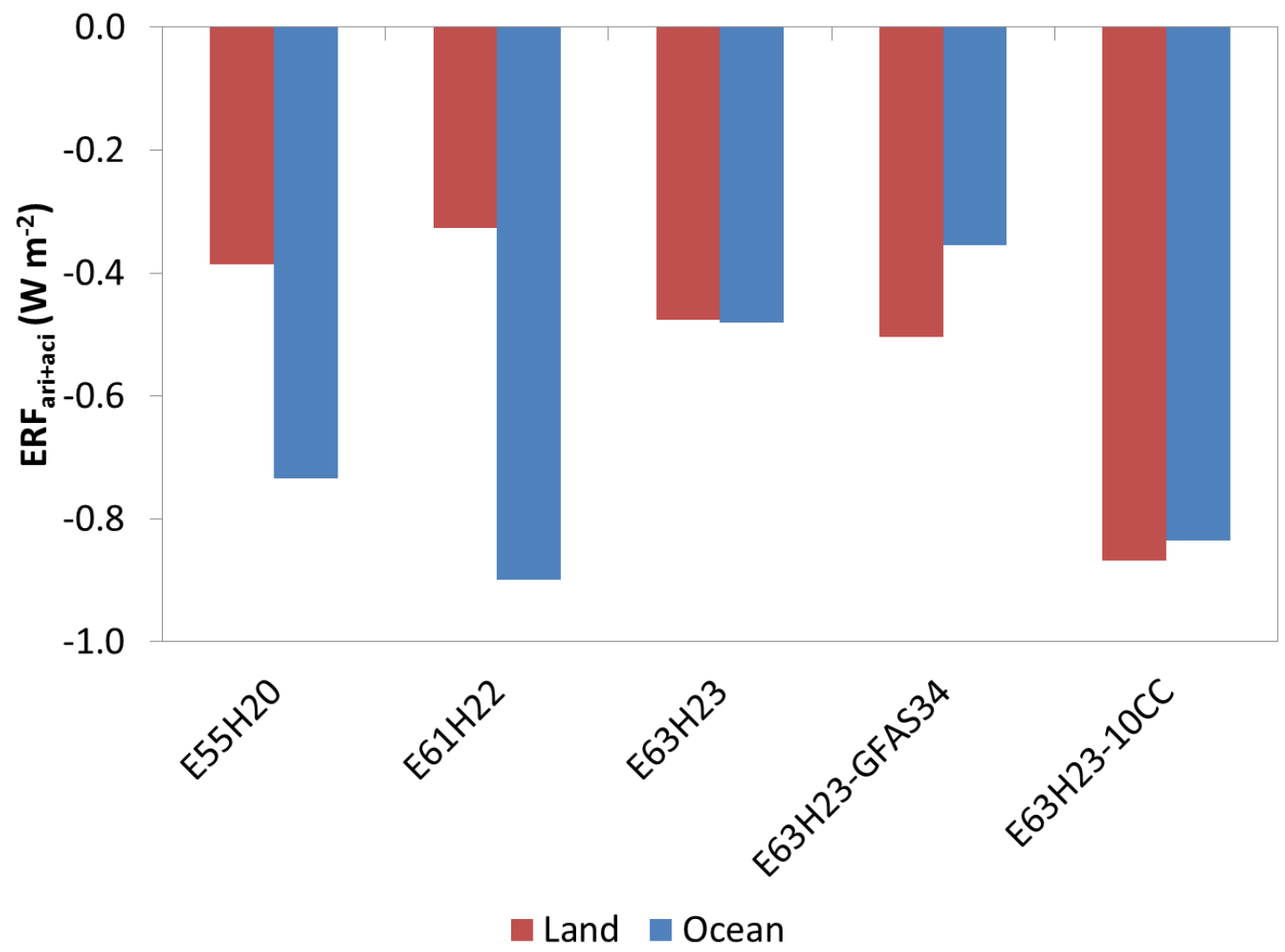

Figure S4: Global mean ERF ari+aci 


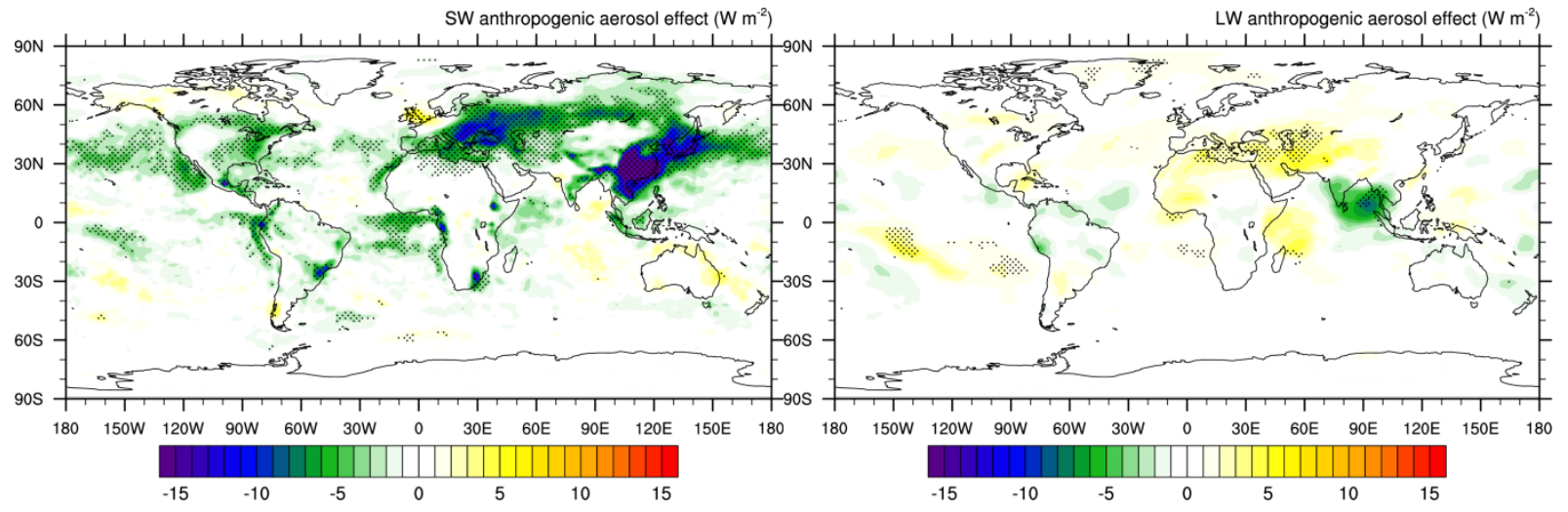

E63H23-GFAS34

E63H23-GFAS34
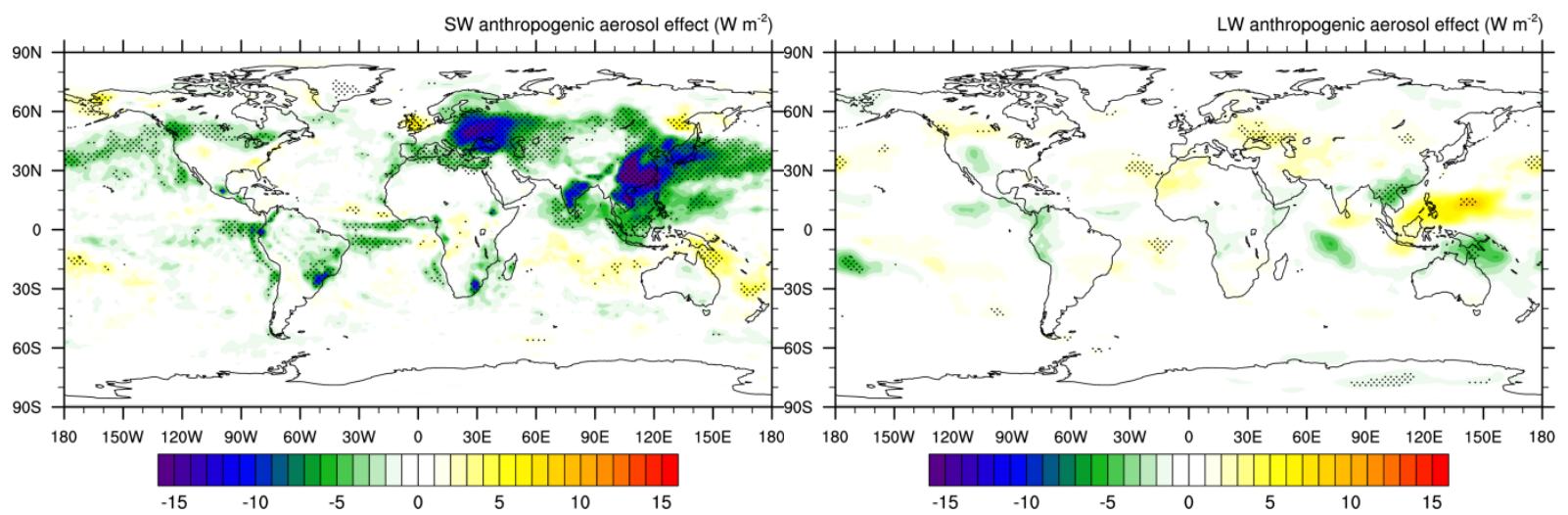

E63H23-CC10

E63H23-CC10
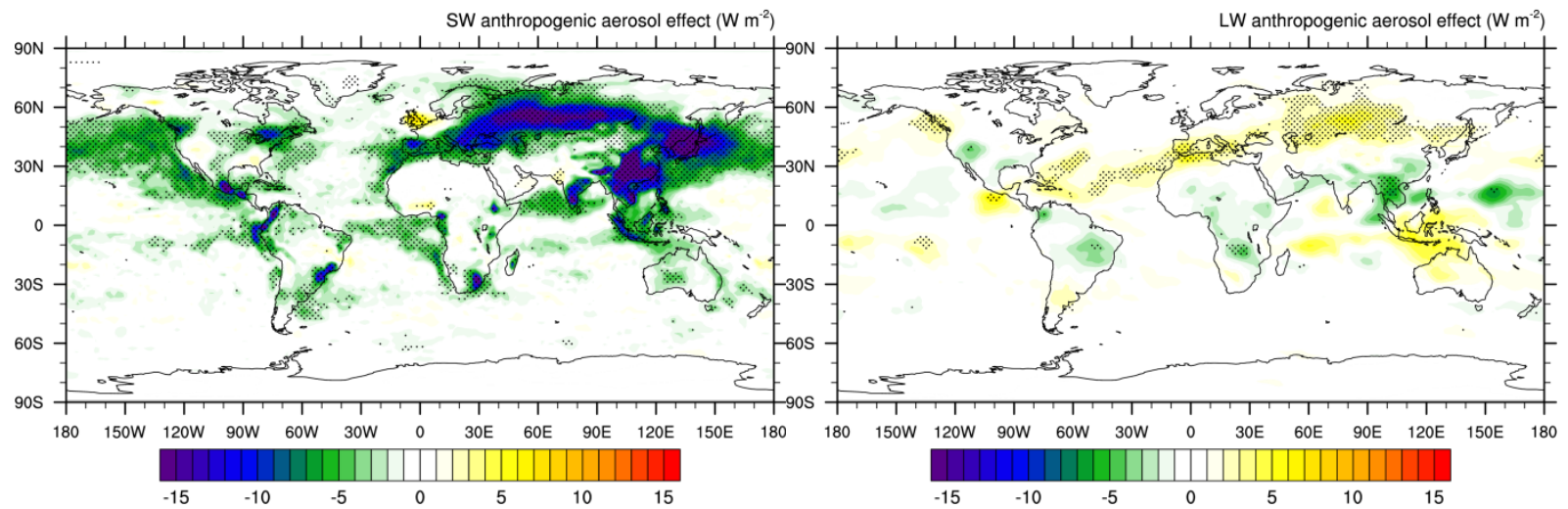


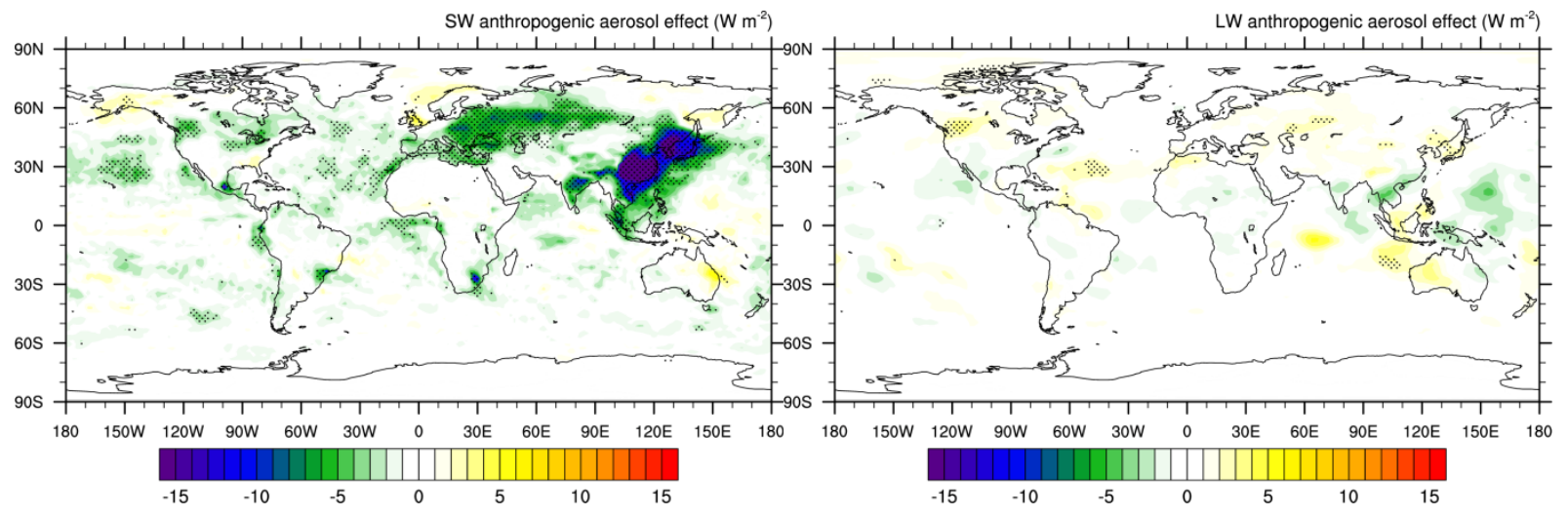

E63H23-GUELLE

E63H23-GUELLE

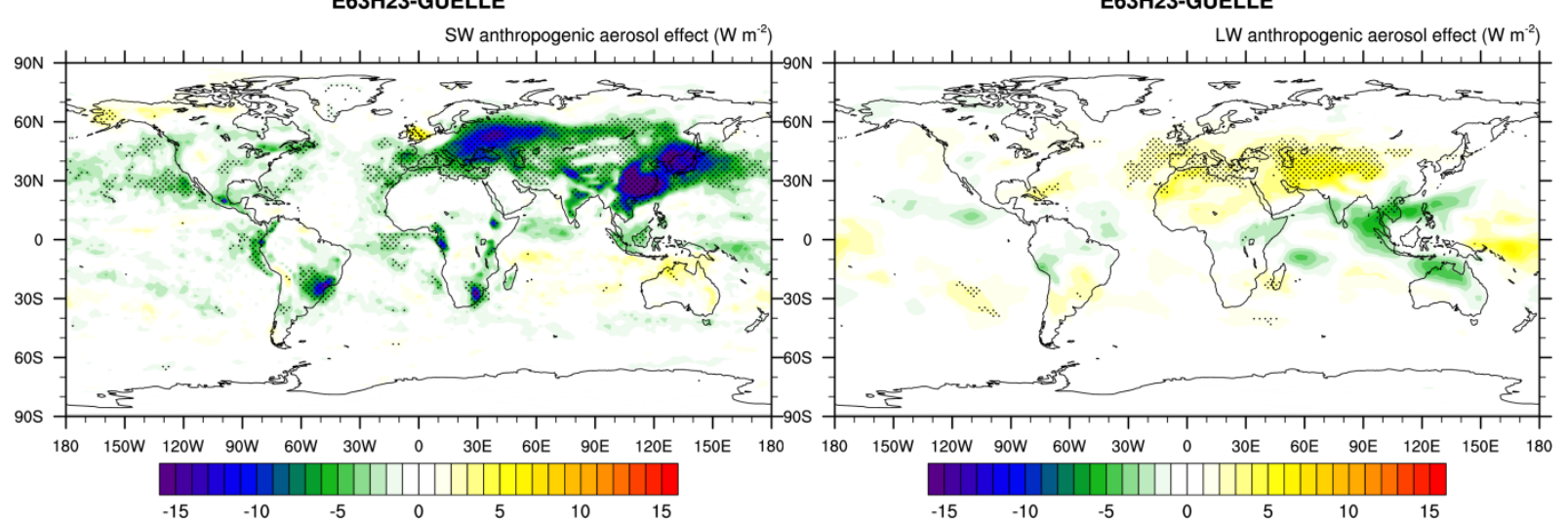

5 Figure S5: Global maps of SW and LW ERF ari+aci of E63H23, E63H23-GFAS34, E63H23-10CC, E63H23-LL and E63H23GUELLE from 20 year free simulations with present day minus pre-industrial aerosol emissions $\left(\mathbf{P D}_{\text {aer }}-\mathbf{P I}_{\text {aer }}\right)$. Hatching indicates statistically significant differences at the $95 \%$ significance level. The false discovery rate is controlled following Wilks (2016).

4 Global mean values of $\mathrm{PD}_{\text {aer }}, \mathrm{PI}_{\mathrm{aer}}, 1 \mathrm{xCO2}$ and $2 \mathrm{xCO} 2$ simulations 


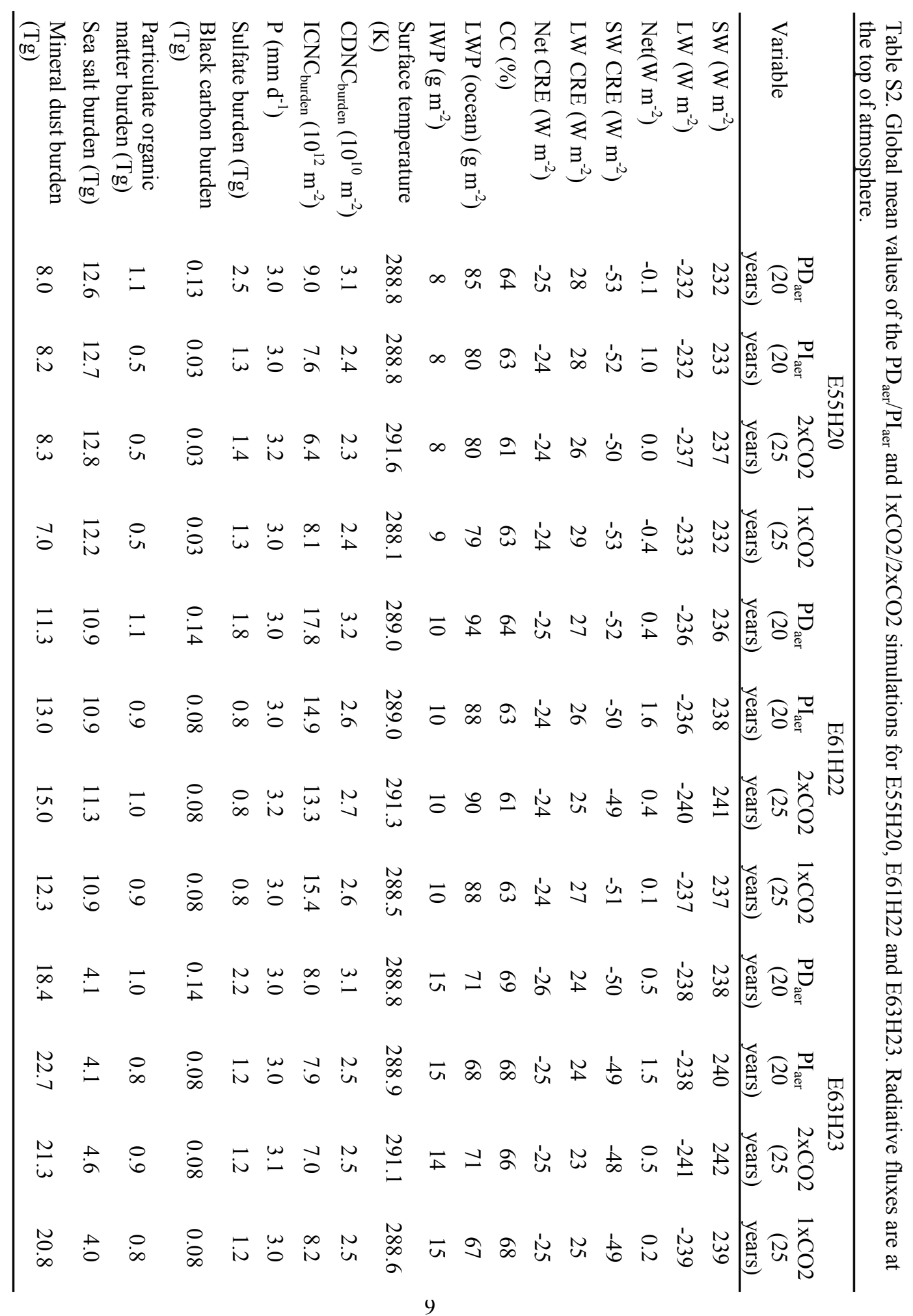


5 Supercooled liquid fraction (SLF)

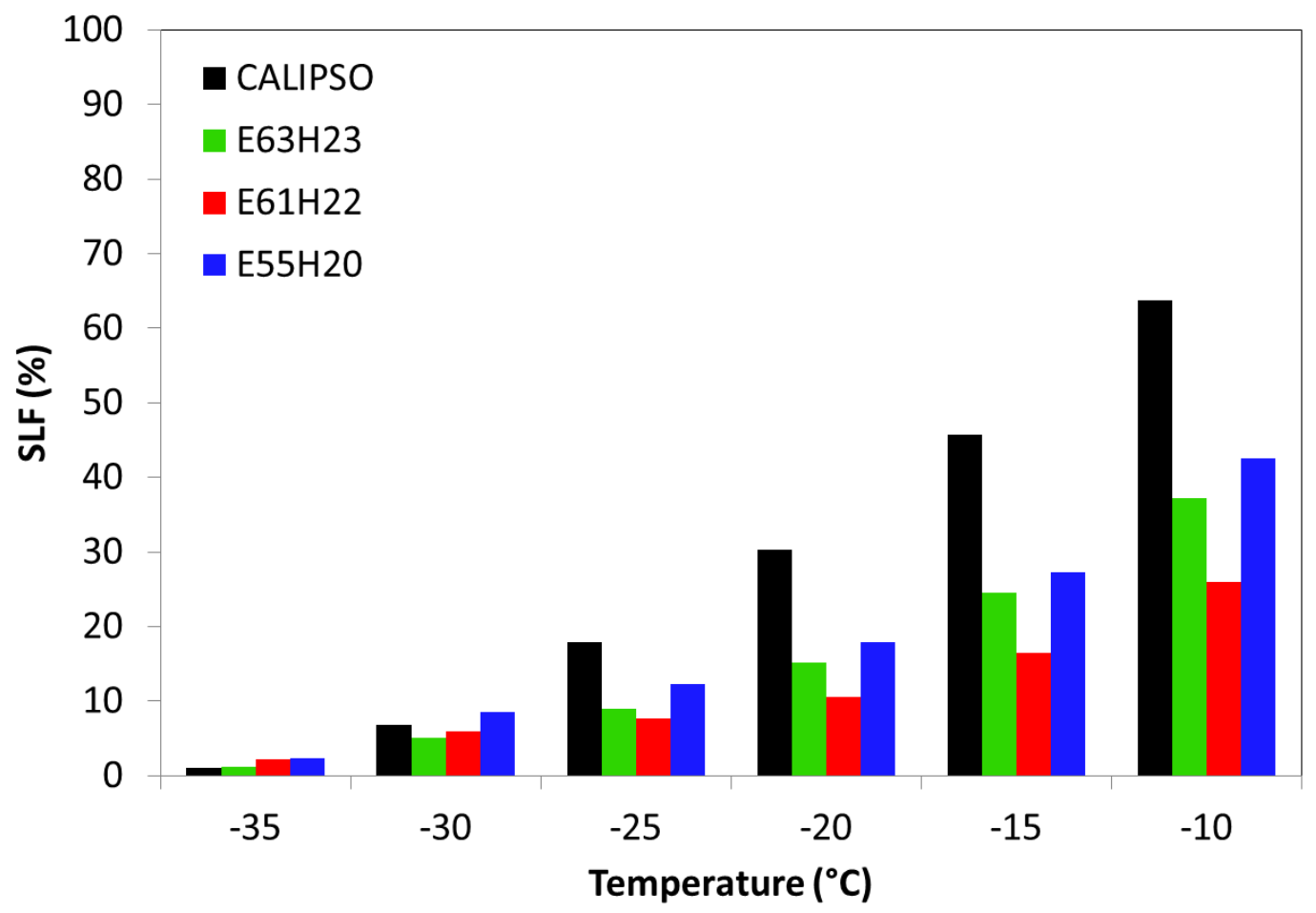

Figure S6: Global mean of SLF (=liquid water content/(liquid water content+IWC)) for clouds with COD $<3$ in different temperature bins for E55H20, E61H22 and E63H23. CALIPSO data is for the years 2006-2010 and the model data is from the PD simulations. 

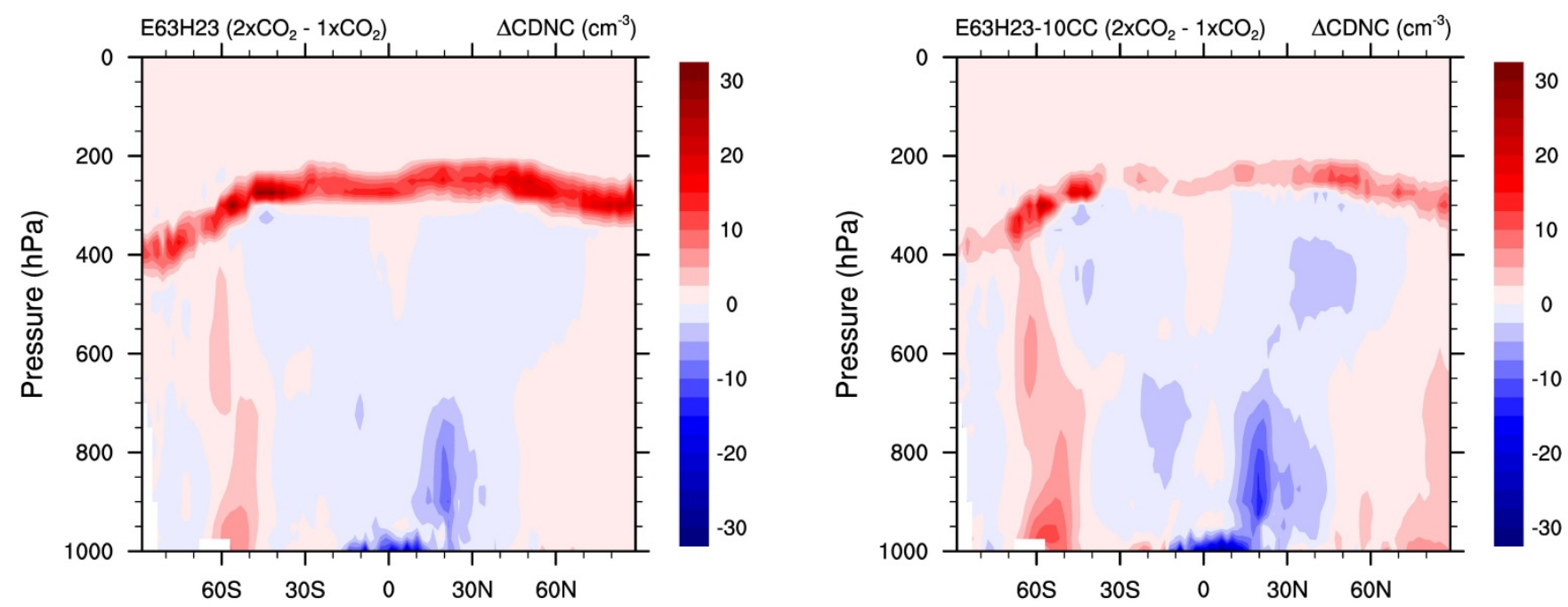

Figure S7: Zonal mean change in in-cloud $\mathrm{CDNC}$ for $\mathrm{E} 63 \mathrm{H} 23$ and $\mathrm{E} 63 \mathrm{H} 23-10 \mathrm{CC}$ for the change from the 1xCO climate to the $2 \times \mathrm{CO}_{2}$ climate. Averages for the last 25 years of the $1 \mathrm{xCO}_{2}$ and $2 \mathrm{xCO}_{2}$ experiments were used to create the figure. 
7 COSP Calipso simulator cloud cover 

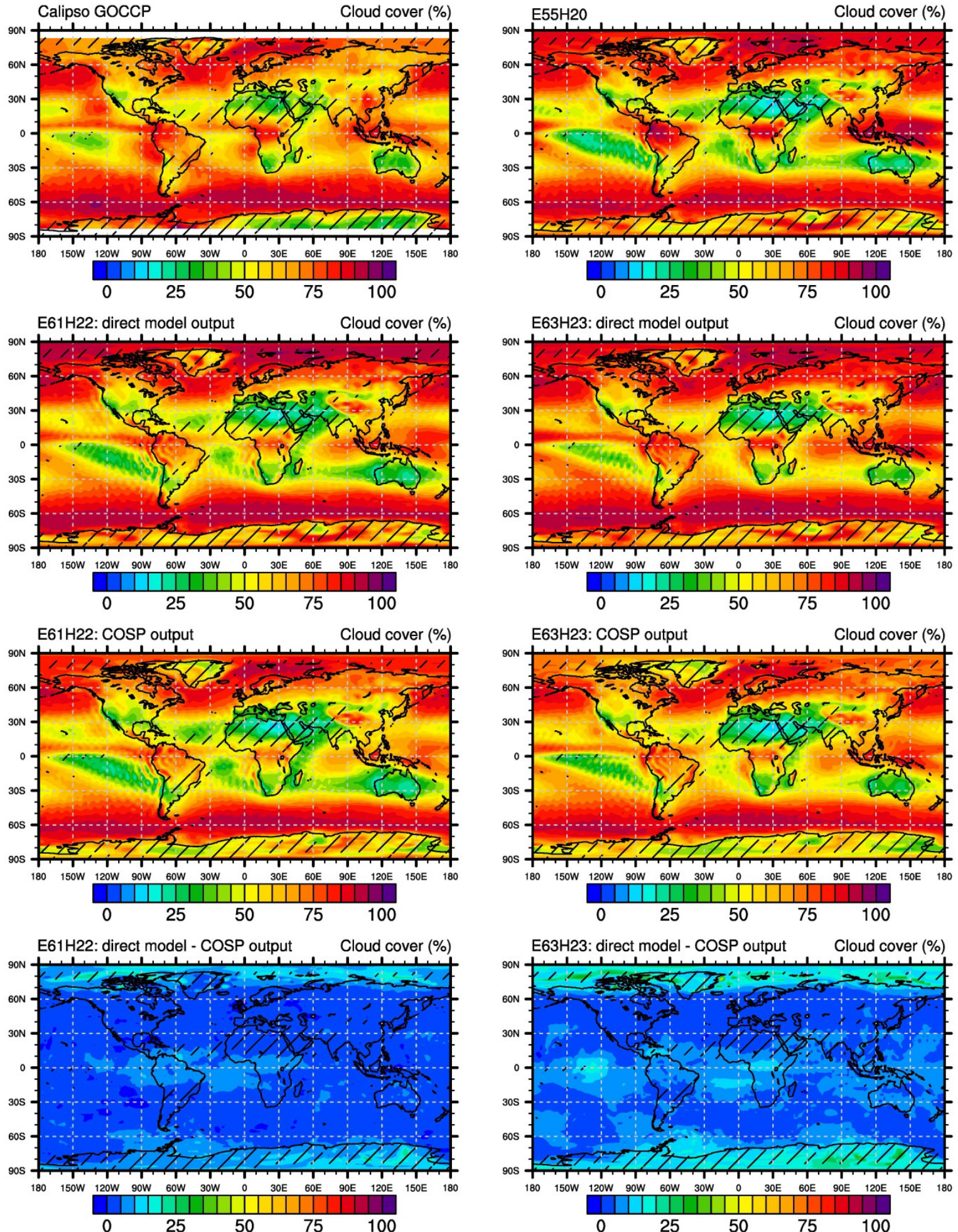
Figure S8: Comparison of annual mean cloud cover of E55H20, E61H22 and E63H23 to CALIPSO GOCCP observations. Areas where the cloud cover of CALIPSO GOCCP, MODIS collection 6.1 and AVHRR-PM differ by more than five percent points are hatched. CALIPSO GOCCP data is for 2006-2010, model data is from the PD simulations. For E61H22 and E63H23 the direct model output, the output of the COSP CALIPSO simulator implemented in those model versions and the difference between direct 5 model output and COSP CALIPSO simulator output is displayed. 